\title{
Polyketone polymer: A new support for direct enzyme immobilization
}

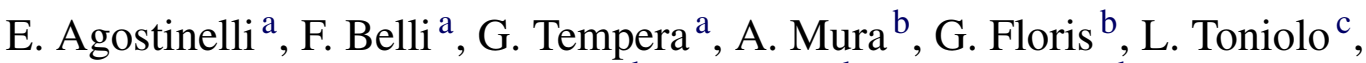

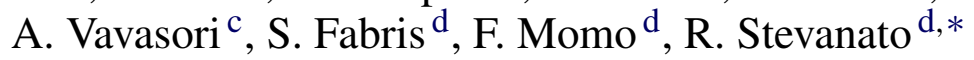 \\ a Department of Biochemical Sciences "A. Rossi Fanelli", University of Rome "La Sapienza” and CNR, \\ Biology and Molecular Pathology Institutes, Rome, Italy \\ ${ }^{\mathrm{b}}$ Department of Applied Sciences in Biosystems, University of Cagliari, Italy \\ c Department of Chemistry, University of Venice "Ca' Foscari", Italy \\ d Department of Physical Chemistry, University of Venice "Ca' Foscari", Italy
}

Received 28 February 2006; received in revised form 13 June 2006; accepted 1 August 2006

\begin{abstract}
Polyketone polymer $-\left[-\mathrm{CO}-\mathrm{CH}_{2} \mathrm{CH}_{2}-\right]_{n}-$, obtained by copolymerization of ethene and carbon monoxide, is utilized for immobilization of three different enzymes, one peroxidase from horseradish (HRP) and two amine oxidases, from bovine serum (BSAO) and lentil seedlings (LSAO). The easy immobilization procedure is carried out in diluted buffer, at $\mathrm{pH} 7.0$ and $3{ }^{\circ} \mathrm{C}$, gently mixing the proteins with the polymer. No bifunctional reagents and spacer arms are required for the immobilization, which occurs exclusively via a large number of hydrogen bonds between the carbonyl groups of the polymer and the - $\mathrm{NH}$ groups of the polypeptidic chain. Experiments demonstrate a high linking capacity of polymer for BSAO and an extraordinary strong linkage for LSAO. Moreover, activity measurements demonstrate that immobilized LSAO totally retains the catalytic characteristics of the free enzyme, where only a limited increase of $K_{\mathrm{M}}$ value is observed. Finally, the HRP-activated polymer is successfully used as active packed bed of an enzymatic reactor for continuous flow conversion and flow injection analysis of hydrogen peroxide containing solutions.
\end{abstract}

() 2006 Elsevier B.V. All rights reserved.

Keywords: Immobilized enzymes; Polyketone polymer; Hydrogen bonds; F.I.A.; Copper containing amine oxidase; Peroxidase

Abbreviations: AO, copper/TPQ containing amine oxidase; BSAO, bovine serum amine oxidase; dppp; 1,3-bis(diphenylphosphino)propane; LSAO, lentil seedling amine oxidase; HRP, horseradish peroxidase

* Corresponding author. Fax: +39041 2348594.

E-mail address: roberto.stevanato@unive.it (R. Stevanato).

\section{Introduction}

Even though the enzyme immobilization is studied since the second half of the 20th Century (Carr and Bowers, 1980 and references therein; Kennedy and White, 1985 and references therein; Gacesa 
and Hubble, 1987), it is still of particular interest (Cao, 2005; Bornscheuer, 2005). Recent studies are addressed towards all fields of the enzyme immobilization to find new applications in all kinds of the enzyme biotechnology, in particular for biomedical applications (Liang et al., 2000; Demers et al., 2002), biosensors (D'Souza, 2001), analytical determinations (Wu and Cheng, 2005; Vila and Tubino, 2001), biotransformations also in organic solvents (Faber, 1999; Ogino and Ishikawa, 2001; Arroyo et al., 2003), synthesis of bioactive compounds (Garcìa-Junceda et al., 2004), and analytical and preparative separations (Girelli and Mattei, 2005; Podgornik and Tennikova, 2002). Moreover, numerous papers have been published concerning new supports for heterogeneous enzymatic catalysis (Kohli and Martin, 2003; Nahalka et al., 2003; Butler, 2000; Merkel et al., 2005), with particular attention to membranes and polymeric films (Rauf et al., 2006; Biegunski et al., 2006), and nanotubes (Kandimalla and Ju, 2006; Martin and Kohli, 2003).

Polymers are used as drug controlled delivery devices (Gayet and Fortier, 1995) and as a matrix for proteins immobilization (D'Urso et al., 1995). Modification of the surface of enzymes, using synthetic biocompatible polymers such as poly(ethylene glycol) (PEG) of various molecular masses (Fortier, 1994; Veronese and Morpurgo, 1999), is a well established tool to increase the functional stability of the proteins and to diminish their blood clearance as well as their immunogenicity.

Investigating new solid supports, we have focalized our attention on a perfectly alternating polyketone which presents a high density of keto groups and, therefore, it has the potentiality to give a large number of hydrogen bonds with the $\mathrm{NH}$ amidic groups of the enzyme surface.

In this work we demonstrate the high immobilizing capacity of the polyketone polymer with respect to different enzymes - horseradish peroxidase (HRP) and two copper/TPQ containing amine oxidases (BSAO and LSAO) - with retention of the catalytic activity and the possibility to use the immobilized enzyme as heterogeneous catalyst of a plug flow microreactor inserted into a flow injection analysis system.

\section{Materials and methods}

\subsection{Reagents, enzymes and supports}

All reagents were purchased from Sigma and used without further purification. The perfectly alternating polyketone polymer was synthesized from carbon monoxide and ethene, using $\left[\mathrm{PdCl}_{2}\right.$ (dppp)] as catalyst precursor in $\mathrm{H}_{2} \mathrm{O}-\mathrm{CH}_{3} \mathrm{COOH}$ as solvent, according to Vavasori et al. (2004). The polyketone showed a limit viscosity number of $0.55 \mathrm{dl} / \mathrm{g}$ in $\mathrm{m}$-cresol at $25^{\circ} \mathrm{C}$, which corresponded to an average viscosity molecular weight of 25,000 u.m.a. (Lommerts and Sikkema, 2000). The white fine powder of the polymer was used without further treatments.

Type II HRP [donor: hydrogen peroxide oxidoreductase, E.C. 1.11.1.7] was from Sigma and had a specific activity of 200 units per mg solid, using pyrogallol as substrate.

AO [amine: oxygen oxidoreductase (deaminating) (copper containing); E.C. 1.4.3.6] from Lens esculenta seedlings (LSAO) was prepared according to Floris et al. (1983) and had a specific activity of $110 \mathrm{IU} / \mathrm{mg}$ of protein using putrescine as substrate. AO from bovine serum (BSAO) was purified according to Turini et al. (1982) with minor modifications and showed a specific activity of $0.28 \mathrm{IU} / \mathrm{mg}$ of protein. One IU corresponds to $1 \mu \mathrm{mol}$ substrate oxidized per min at $25^{\circ} \mathrm{C}$.

Spectrophotometric measurements were carried out using a Beckman DU 640 instrument.

\subsection{Voidage measurement}

The voidage, i.e. the ratio between the liquid volume and the volume of the polymer slurry equilibrated with water, was measured adding a known volume of water to $500 \mathrm{mg}$ of polymer powder until a thin layer of water was over the completely hydrated slurry. The liquid volume is the difference between the added volume of water and the supernatant volume. The difference between the slurry volume and the liquid volume is the volume of the polymer.

\subsection{Determination of the amount of the water accessible keto groups}

It has been followed the analytical method of Roe and Mitchell (1951) based on the titration with hydrox- 
ylamine hydrochloride of the polymer carbonyl groups and recording the $\mathrm{pH}$ variation due to the hydrogen ions produced by the reaction. The correlation between the $\mathrm{pH}$ change and the carbonyl concentration was obtained by a calibration curve previously drawn using acetone as reference standard.

\subsection{Immobilization procedure}

The enzyme immobilization was carried out by gently mixing end-over-end at $3{ }^{\circ} \mathrm{C}$ for different time (generally $20 \mathrm{~h}$ ) the polymer powder, previously washed repeatedly with distilled water, with the enzyme dissolved in $10 \mathrm{mM}$ potassium phosphate buffer, $\mathrm{pH}$ 7.0. Aliquots of the supernatant were drawn up to verify the advancement of the immobilization.

\subsection{Determination of the linkage efficiency}

For all the three proteins, the amount of linked enzyme was determined by measuring both the activity and the residual protein content on the supernatant solution. The protein content was determined using the following absorbance values:

\begin{tabular}{llr}
\hline Enzyme & $\lambda$ & \multicolumn{1}{c}{$\varepsilon$} \\
\hline HRP & 401 & 63,000 \\
BSAO & 278 & 390,000 \\
LSAO & 280 & 245,000 \\
\hline
\end{tabular}

\subsection{Activity measurement}

HRP activity was measured, in the presence of hydrogen peroxide, by monitoring the initial rate of absorbance increasing at $511 \mathrm{~nm}$ of the colored dye produced by the catalyzed peroxidative reaction of two leuco dyes, 4-aminophenazone and 3,5-dichloro-2hydroxybenzensulfonic acid, using a molar absorbance value of $2.3 \times 10^{4} \mathrm{M}^{-1} \mathrm{~cm}^{-1}$. The amount of linked enzyme was calculated by the difference between the initial rate values of the supernatant at the start and at the end of the linked reaction.

BSAO activity was measured by monitoring $\mathrm{H}_{2} \mathrm{O}_{2}$ production, originated by the oxidative deamination of the substrate spermine, at $511 \mathrm{~nm}$ using a HRP-dyes coupled assay, according to the following reactions
(Stevanato et al., 1990; Wilmot, 2003):

$$
\begin{gathered}
\mathrm{R}-\mathrm{CH}_{2}-\mathrm{NH}_{2}+\mathrm{H}_{2} \mathrm{O}+\mathrm{O}_{2} \stackrel{\mathrm{AO}}{\longrightarrow} \mathrm{R}-\mathrm{CHO} \\
+\mathrm{H}_{2} \mathrm{O}_{2}+\mathrm{NH}_{3}
\end{gathered}
$$

Dye ${ }_{\text {red }}+2 \mathrm{H}_{2} \mathrm{O}_{2} \stackrel{\text { HRP }}{\longrightarrow}$ Dye $_{\text {ox }}+4 \mathrm{H}_{2} \mathrm{O}$

LSAO activity was measured recording the oxygen uptake by a Clark electrode, using 1,4-diaminebutane (putrescine) as substrate as previously reported (Floris et al., 1983).

\subsection{Flow injection analysis system}

The flow injection analysis system was made up of the following components: a Beckman 112 Solvent Delivery Module pump connected with an Altex $213 \mathrm{~A}$ injection valve equipped with a $230 \mu \mathrm{lloop}$; an Amersham Biosciences Tricorn 5/20 column (volume $390 \mu$ l) filled with the immobilized enzyme; a Beckman DU 7 spectrophotometer as detector coupled with a quartz flow cell (Hellma) characterized by a $8 \mu$ l cell volume. The temperature was assured by a Haake F3 thermostat.

\section{Results}

\subsection{The polyketone polymer}

The palladium-catalyzed copolymerization of ethene and carbon monoxide produces an alternating polyketone of a high crystallinity (Sommazzi and Garbassi, 1997; Vavasori et al., 2004) of general formula:<smiles>CCCCCC(C)C</smiles>

Due to the close presence of the polar keto groups, the polymer presents a high liquid volume value $(8.2 \mathrm{ml} / \mathrm{g})$, larger than twice of the commercial sepharoses (Amersham Biosciences, 2002), probably because of the high possibility of hydrogen bonds between the keto groups and the water molecules, and no restriction due to cross bonds are present. 
Table 1

Average viscosity molecular weight $\left(M_{\mathrm{w}}\right)$, liquid volume and voidage of the polyketone

\begin{tabular}{llll}
\hline$M_{\mathrm{w}}$ & $\begin{array}{l}\text { Slurry volume } \\
\left(V_{\mathrm{s}}\right)(\mathrm{ml} / \mathrm{g} \\
\text { polymer })\end{array}$ & $\begin{array}{l}\text { Liquid volume } \\
\left(V_{\mathrm{l}}\right)(\mathrm{ml} / \mathrm{g} \\
\text { polymer })\end{array}$ & Voidage $\varepsilon=V_{\mathrm{l}} / V_{\mathrm{s}}$ \\
\hline 25,000 & 9.2 & 8.2 & 0.89 \\
\hline
\end{tabular}

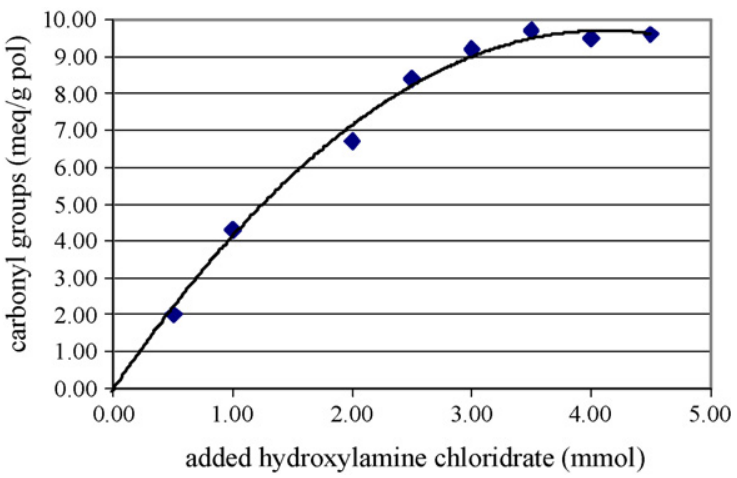

Fig. 1. Titration of the water accessible carbonyl groups present in the polyketone polymer.

Some characteristics of the polyketone are reported in Table 1.

The ability of the polyketone polymer to link proteins was correlated to the carbonyl groups accessible to the solvent. Thus, we titrated the carbonyl groups of the polymer with hydroxylamine hydrochloride, according to the method of Roe (Roe and Mitchell, 1951). Fig. 1 shows the concentration of carbonyl groups per gram polymer versus the concentration of added hydroxylamine hydrochloride. A value of about $9.6 \mathrm{meq}$ carbonyl groups per gram polymer is obtained. Considering that the polymer presented a carbonyl group every 56 u.m.a., corresponding to a theoretical value of about $18 \mathrm{meq} / \mathrm{g}$ polymer, the carbonyl groups accessible to water represents about $53 \%$ of the total.

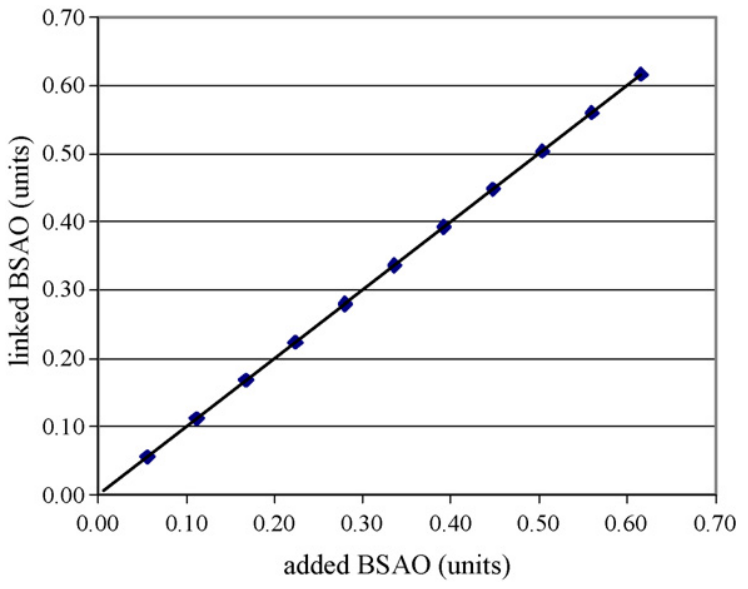

Fig. 2. Linking ability of polyketone polymer with respect to BSAO.

\subsection{Immobilization of BSAO on polyketone polymer}

Fig. 2 shows the linking ability of the polymer to BSAO, expressed as number of linked enzymatic units versus the number of total added enzymatic units. To the batch, consisting in $100 \mathrm{mg}$ of polymer suspended in $900 \mu \mathrm{l}$ of a $10 \mathrm{mM}$ phosphate buffered solution, pH 7.0, containing $150 \mathrm{mM} \mathrm{NaCl}, 11$ consecutive aliquots of $100 \mu \mathrm{l}$ BSAO ( $11 \mu \mathrm{M}$; 0.06 units) were added, mixing gently end-over-end at $3{ }^{\circ} \mathrm{C}$, until no protein content and BSAO activity in the supernatant were recorded after each addition. No linkage reagents or spacer arms is required for the protein immobilization. Considering the trend of the graph, we hypothesize that the linking ability of the polymer is not exhausted and a larger amount of enzyme could be immobilized.

Similar results are obtained using HRP or LSAO (Table 2); the different yields of linked enzymes obtained are probably due to the different protein

Table 2

Immobilization tests using the three different enzymes

\begin{tabular}{|c|c|c|c|c|c|c|c|c|}
\hline & \multirow[t]{2}{*}{ Enzyme } & \multirow{2}{*}{$\begin{array}{l}\text { Polymer } \\
\text { amount }(\mathrm{g})\end{array}$} & \multirow{2}{*}{$\begin{array}{l}\text { Enzyme } \\
\text { added (units) }\end{array}$} & \multirow[t]{2}{*}{ Contact time (h) } & \multirow[t]{2}{*}{ Enzyme linked (units) } & \multirow{2}{*}{$\begin{array}{l}\text { Enzyme } \\
\text { immobilization (\%) }\end{array}$} & \multicolumn{2}{|c|}{$[\text { Enzyme }]_{\text {slurry }}$} \\
\hline & & & & & & & units $/ \mathrm{ml}$ & $\mathrm{mg} / \mathrm{ml}$ \\
\hline 1 & BSAO & 0.1 & 0.62 & $\mathrm{a}$ & 0.62 & 100 & 0.66 & 2.36 \\
\hline 2 & LSAO & 0.1 & 115 & 20 & 85 & 73.9 & 92 & 0.84 \\
\hline 3 & HRP & 0.1 & 200 & 20 & 49 & 24.5 & 53 & 0.27 \\
\hline
\end{tabular}

a The enzyme was added by consecutive aliquots. The overall time was several days. 
concentrations or, particularly in the case of the commercial peroxidase, to the poor enzyme purity.

\subsection{Catalytic characteristic of linked LSAO}

In the case of LSAO, several experiments were carried out in order to test the linkage stability. In particular, a repeated washing of the polymer supported enzyme with $1 \mathrm{M}$ phosphate buffer and $1 \mathrm{M} \mathrm{NaCl}$ did not take off the enzyme from the polymer. In order to verify the activity retention of the immobilized enzyme, initial rate measurements of the LSAO-activated polymer were carried out by recording the oxygen consumption by a Clark electrode. Some parameters of functionality and stability of the activated polymer were also calculated and the results are reported in Table 3 and in Figs. 3 and 4, in comparison with those related to the free enzyme found following the kinetic procedures of Moosavi-Nejad et al. (2001) and Floris et al. (1983).

From the data reported in Table 3 it appears that the catalytic characteristic of the free enzyme is well preserved after immobilization. The slight increase of the $K_{\mathrm{M}}$ value could depend on: (i) restricted mobility of the linked enzyme; (ii) structural perturbations of the protein and the tightening of the access of the reactant to the enzyme's active site; (iii) external mass transfer resistance (Gacesa and Hubble, 1987).

The $\mathrm{pH}$ curves, clearly similar in native and immobilized LSAO, suggest that the linkage between the

Table 3

Activity and stability parameters of linked and free lentil seedling amine oxidase

\begin{tabular}{lcc}
\hline & LSAO & \\
\cline { 2 - 3 } & Free & Linked \\
\hline $\begin{array}{l}K_{\mathrm{M}}(\mathrm{mM}) \\
\begin{array}{l}\text { Temperature of maximum } \\
\text { activity }\left({ }^{\circ} \mathrm{C}\right)^{\mathrm{a}}\end{array}\end{array}$ & 0.2 & 0.5 \\
$\begin{array}{l}\text { Temperature of inactivation } \\
\left({ }^{\circ} \mathrm{C}\right)^{\mathrm{a}}\end{array}$ & 55 & 55 \\
$\begin{array}{l}\text { Temperature of slope } \\
\text { discontinuity in the } \\
\quad \text { Arrhenius plot }\left({ }^{\circ} \mathrm{C}\right)^{\mathrm{a}}\end{array}$ & 30 & 60 \\
pH of maximum activity & & 30 \\
\hline $\begin{array}{l}\text { a Moosavi-Nejad et al. }(2001) . \\
\text { b Floris et al. }(1983) .\end{array}$ & 7.0 & 7.0 \\
\hline
\end{tabular}

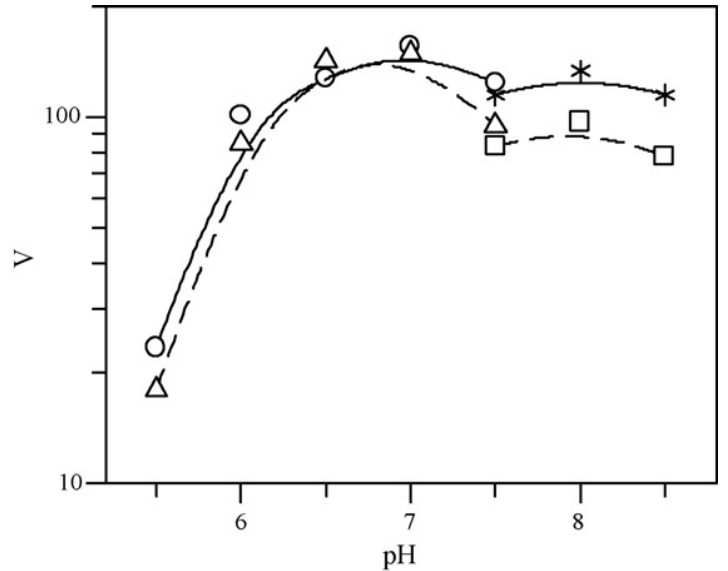

Fig. 3. Effect of $\mathrm{pH}$ and buffer on free LSAO activity. The buffers used were $(\bigcirc) 100 \mathrm{mM}$ potassium phosphate and $100 \mathrm{mM}$ Tris/HCl $(*) .(\Delta)$ and $(\square)$ represent the immobilized LSAO on polyketone polymer using the same buffer as the free enzyme.

polyketone and LSAO might occur via hydrogen bond on the surface amidic group of the polypeptide chain, without involving in any case the active site of the enzyme.

Also in the case of the behaviors of activity with temperature, no significant change between free and immobilized LSAO is observed (Fig. 4).

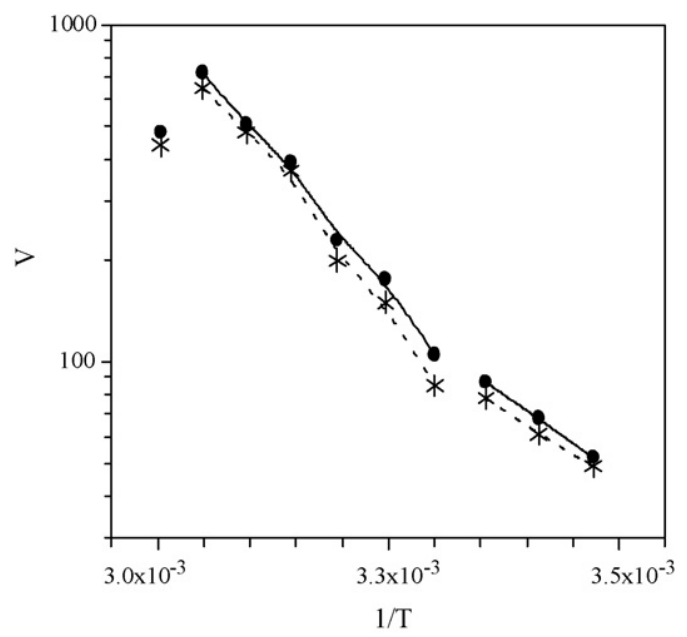

Fig. 4. Effect of temperature on the rate of the reaction catalyzed by LSAO. Standard assay conditions were used. Asterisks (*) represent the immobilized LSAO on polyketone polymer. 


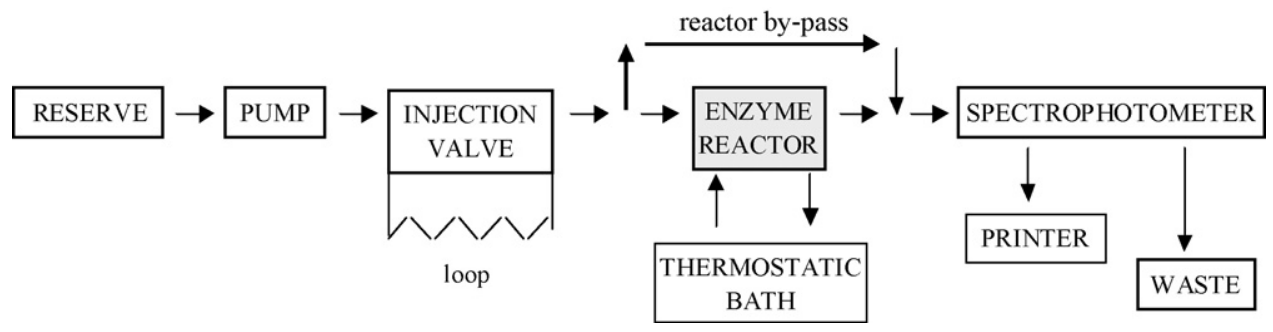

Fig. 5. Block diagram of the flow injection analysis system.

\subsection{Biotechnological applications of polyketone polymer immobilized peroxidase}

The water permeability of the polyketone polymer was measured by recording the resistance to the pressure due to the polymer packed into a flow column (inside diameter $5 \mathrm{~mm}$; length $20 \mathrm{~mm}$ ). Different experiments, carried out using several buffers of different concentrations, demonstrated negligible values of hydrostatic pressure resistance (P [2 bar) working till flow rates of $5 \mathrm{ml} / \mathrm{min}$. The same column was filled with the peroxidase-activated polymer (63 units/ml slurry) and the enzyme reactor was inserted into the flow injection analysis system schematized in Fig. 5.

We used this system to carry out experiments of enzymatic heterogeneous catalysis under two working conditions: continuous flow conversion and flow injection analysis. In the first case a continuous flow of buffered $\mathrm{H}_{2} \mathrm{O}_{2}$ solution, containing the reduced dyes, passed through the enzymatic reactor containing the immobilized peroxidase. In Fig. 6 some typical spectrophotometric responses to the absorbance increase are reported.

Fig. 7 shows the spectrophotometric responses to injections of $230 \mu \mathrm{l} 5 \mu \mathrm{M} \mathrm{H}_{2} \mathrm{O}_{2}$ dissolved in phosphate buffer containing the reduced dyes. In both the cases the color development confirmed that the catalytic activity of the immobilized HRP was preserved. Furthermore, several months were elapsed between the enzymes immobilization and the biotechnological applications without appreciable loss in activity; this evidenced a good stability of the enzyme and its long-lived immobilization to the polyketone polymer, such as confirmed by the good reproducibility of the experimental results.

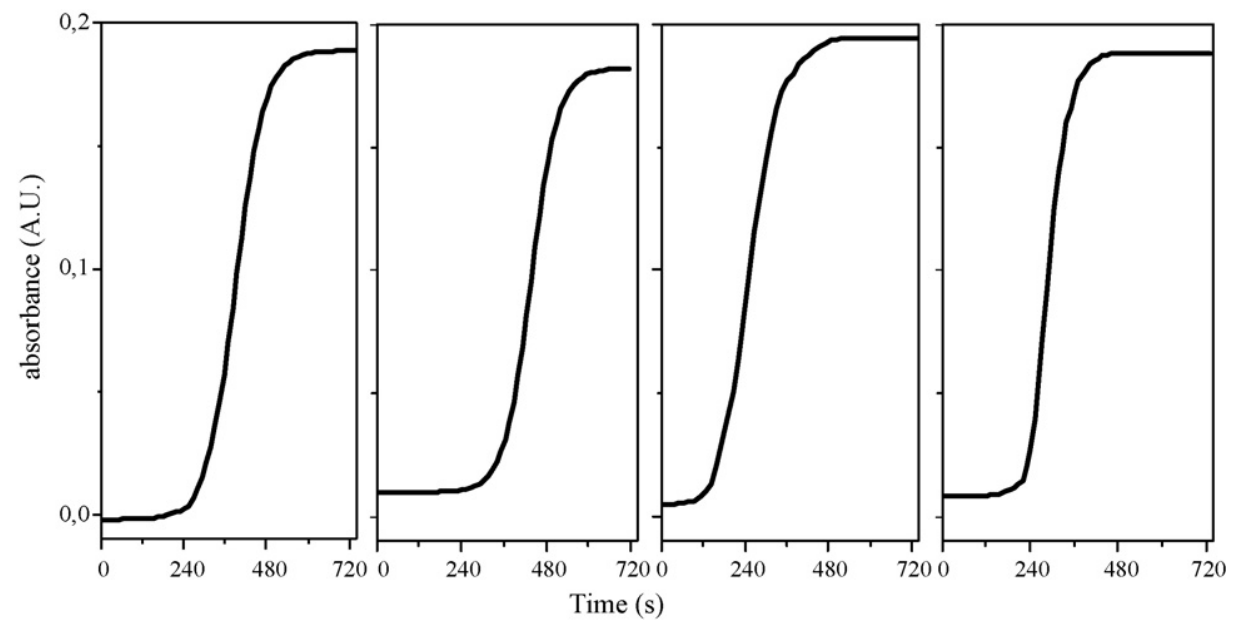

Fig. 6. Typical spectrophotometric responses to a continuous flow of buffered $\mathrm{H}_{2} \mathrm{O}_{2}$ solution containing the reduced dyes. The solution contained $20 \mu \mathrm{M} \mathrm{H}_{2} \mathrm{O}_{2}, 3 \mathrm{mM}$ 4-aminophenazone, $3 \mathrm{mM} \mathrm{3,5-dichloro-2-hydroxybenzensulfonic} \mathrm{acid} \mathrm{in} 10 \mathrm{mM}$ phosphate buffer, $\mathrm{pH}$ 7.0. The flow rate was $2 \mathrm{ml} / \mathrm{min}$ and the temperature $22^{\circ} \mathrm{C}$. The reactor was completely filled with $390 \mu \mathrm{lof} 63 \mathrm{units} / \mathrm{ml}$ peroxidase-activated polymer. These experiments were carried out in different days until after two months from the immobilization. R.S.D. was less than $3 \%$. 


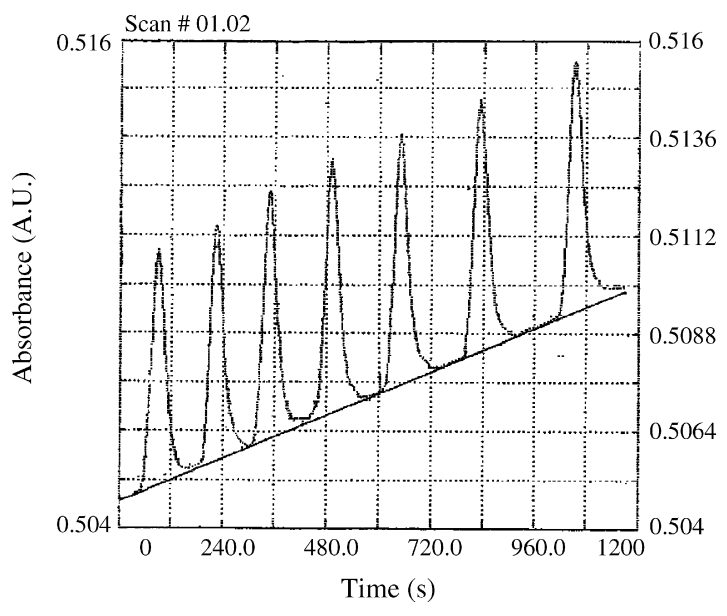

Fig. 7. Spectrophotometric response to injection of $230 \mu 1$ of $5 \mu \mathrm{M}$ $\mathrm{H}_{2} \mathrm{O}_{2}$ dissolved in $10 \mathrm{mM}$ phosphate buffer, $\mathrm{pH} 7.0$, containing the reduced dyes. The carrier solution was the same without $\mathrm{H}_{2} \mathrm{O}_{2}$. The other experimental conditions were the same of those reported in Fig. 6. The signal noise ratio was better than 40:1, whilst R.S.D. was less than $2.5 \%$. The drift of the base line is an instrumental limit due to the high scale expansion.

When not used, the activated polymer was kept at $3{ }^{\circ} \mathrm{C}$, in $10 \mathrm{mM}$ phosphate buffer, $\mathrm{pH}$ 7.0.

\section{Discussion}

The polyketone, owing to its high number of keto groups, can form hydrogen bonds with the $-\mathrm{NH}$ groups of the polypeptidic chain. In particular, the polyketone chain showing two consecutive carbonyl groups approximately separated by the same distance of six bond lengths can lay between two consecutive $-\mathrm{NH}$ groups located on the same side of the polypeptide chain (Fig. 8). Moreover, additional hydrogen bonds<smiles></smiles>

Fig. 8. Schematic representation of the possible hydrogen bonds between the carbonylic groups of the polyketone polymer and the $-\mathrm{NH}$ groups of the polypeptidic chain. between the $-\mathrm{C}=\mathrm{O}$ groups of the polymer and the positively charged or polar functional groups of the aminoacid lateral chains are also possible, making the polyketone polymer a suitable support for enzyme immobilization.

The different length of the peptidic bond, which is about $15 \%$ shorter than a carbon-carbon bond, appears not to affect the possibility of a large number of hydrogen bonds. This can be due to the flexibility of the globular structure of both the polymer and the proteins, owing to the lack of cross bonds between different parts of the polypeptidic and the polymeric chains.

In any case, the possibility of a large number of hydrogen bonds, allowed by the chemical and sterical structure of the polymer, can account for its strong immobilization capacity. Furthermore, the catalytic stability of the linked enzyme is assured by the same interactions, which give stability to the secondary and tertiary structure of the enzymes.

\section{Conclusions}

The interest of this study is summarized in the following points:

- the polyketone polymer is able to immobilize different kinds of enzymes up to high concentrations;

- the immobilization procedure is simple and it is carried out in aqueous phase, gently mixing the protein with the polymer in diluted buffer at neutral $\mathrm{pH}$ and $3{ }^{\circ} \mathrm{C}$;

- nor coupling or bifunctional reagents and spacer arms are required for the immobilization, which occurs exclusively via hydrogen bonds;

- linked enzymes appear to be stable, maintaining completely their catalytic properties for long time; this is probably due to the type of bond, flexible and compatible with the delicate protein structure;

- the enzyme-activated polymer can be packed into a microreactor for biotransformation or analytical determinations.

In conclusion, the polyketone appears a promising support for enzyme immobilization for industrial biotransformations, analytical determinations and mainly for biomedical applications. In fact, the polyamine degrading enzymes BSAO and LSAO are good candidates for immobilization into polyketone and also, 
for surface derivatization by biocompatible polymeric structures (Demers et al., 2001), with the aim of increasing their plasmatic half-life or their target ability under injectable form.

Our future investigations will focus on synthesis of biocompatible polymeric microparticles linked to BSAO and LSAO which function as carriers and stabilizers, resulting in a decrease of drug toxicity and an increase of anticancer therapeutic efficacy (Maeda et al., 1992), a promising strategy particularly against multidrug resistant human cancer cells (Calcabrini et al., 2002; Averill-Bates et al., 2005).

\section{Acknowledgements}

We are grateful to Dr. Mariangela Bertelle for her precious technical assistance. Thanks are due to "Fondazione Sovena" for the scholarship given to Giampiero Tempera for supporting his Ph.D. This work was partially supported by the Ministero della Sanità (1\% Fondo Sanitario Nazionale), the Italian MIUR (Ministero dell'Istruzione, dell'Università e della Ricerca) and by funds MIUR-PRIN 2005 (Cofin) (EA).

\section{References}

Amersham Biosciences, 2002. Affinity Chromatography, Principles \& Methods. Amersham Biosciences, Uppsala, 155 pp.

Arroyo, M., de la Mata, I., Acebal, C., Castillon, M.P., 2003. Biotechnological applications of penicillin acylase: state-of-theart. Appl. Microbiol. Biotechnol. 60 (5), 507-514.

Averill-Bates, D.A., Cherif, A., Agostinelli, E., Tanel, A., Fortier, G., 2005. Anti-tumoral effect of native and immobilized bovine serum amine oxidase in a mouse melanoma model. Biochem. Pharmacol. 69 (12), 1693-1704.

Biegunski, A.T., Michota, A., Bukowska, J., Jackowska, K., 2006. Immobilization of tyrosinase on poly(indole-5-carboxylic acid) evidenced by electrochemical and spectroscopic methods. Bioelectrochemistry 69 (1), 41-48.

Bornscheuer, U.T., 2005. Trends and challenges in enzyme technology. Adv. Biochem. Eng. Biotechnol. 100, 181-203.

Butler, J., 2000. Solid supports in enzyme-linked immunosorbent assay and other solid-phase immunoassays. Methods 22 (1), 4-23.

Calcabrini, A., Arancia, G., Marra, M., Crateri, P., Befani, O., Martone, A., Agostinelli, E., 2002. Enzymatic oxidation products of spermine induce greater cytotoxic effects on human multidrugresistant colon carcinoma cells (LoVo) than on their wild-type counterparts. Int. J. Cancer 93, 43-52.
Cao, L., 2005. Immobilised enzymes: science or art? Curr. Opin. Chem. Biol. 9, 217-226.

Carr, P.W., Bowers, L.D., 1980. Immobilization of active biochemicals. In: Elving P.J. and Winefordner J.D. (Eds.), Immobilized Enzymes in Analytical and Clinical Chemistry. John Wiley \& Sons, New York, pp. 148-195.

Demers, N., Agostinelli, E., Averill-Bates, D.A., Fortier, G., 2001. Immobilization of native and poly(ethylene glycol)-treated ('PEGylated') bovine serum amine oxidase into a biocompatible hydrogel. Biotechnol. Appl. Biochem. 33, 201-207.

D'Souza, S.F., 2001. Immobilization and stabilization of biomaterials for biosensors applications. Appl. Biochem. Biotechnol. 96 (1-3), 225-238.

D’Urso, E.M., Jean-Francois, J., Doillon, C.J., Fortier, G., 1995. Poly(ethylene glycol)-serum albumin hydrogel as matrix for enzyme immobilization: biomedical applications. Artif. Cells Blood Substit. Immobil. Biotechnol. 23 (5), 587-595.

Faber, K., 1999. Biotransformations in Organic Chemistry. SpringerVerlag, Berlin, $453 \mathrm{p}$.

Floris, G., Giartosio, A., Rinaldi, A., 1983. Diamine oxidase from Lens Esculenta seedlings: purification and properties. Phytochemistry 22, 1871-1874.

Fortier, G., 1994. Biomedical applications of enzymes and their polyethylene glycol adducts. Biotechnol. Genet. Eng. Rev. 12, 329-356.

Gacesa, P., Hubble, J., 1987. Immobilization of enzymes. In: Taylor and Francis (Eds.), Enzyme Technology. Open University Press, Oxford, pp. 80-89.

Garcìa-Junceda, E., Garcìa-Garcìa, J.F., Bastida, A., FernàndezMayoralas, A., 2004. Enzymes in the synthesis of bioactive compounds: the prodigious decades. Bioorg. Med. Chem. 12, $1817-1834$.

Gayet, J.C., Fortier, G., 1995. Drug release from new bioartificial hydrogel. Artif. Cells Blood Substit. Immobil. Biotechnol. 23 (5), 605-611.

Girelli, A.M., Mattei, E., 2005. Application of immobilized enzyme reactor in on-line high performance liquid chromatography: a review. J. Chromatogr. B. 819 (1), 3-16.

Kandimalla, V.B., Ju, H., 2006. Binding of acetylcholinesterase to multiwall carbon nanotube-cross-linked chitosan composite for flow-injection amperometric detection of an organophosphorous insecticide. Chemistry 12 (4), 1074-1080.

Kennedy, J.F., White, C.A., 1985. Principles of immobilization of enzymes. In: Wiseman, A. (Ed.), Handbook of Enzyme Biotechnology. Hellis Horwood Ltd., Chichester, pp. 147-207.

Kohli, P., Martin, C.R., 2003. Smart nanotubes for biomedical and biotechnological applications. Drug New Perspect. 16 (9), 566-573.

Liang, J.F., Li, Y.T., Yang, V.C., 2000. Biomedical applications of immobilized enzymes. J. Pharm. Sci. 89 (8), 979-990.

Lommerts, B.J., Sikkema, D.J., 2000. Synthesis and structure of a new polyalcohol. Macromolecules 33, 7950-7954.

Maeda, H., Seymour, L.W., Miyamoto, Y., 1992. Conjugates of anticancer agents and polymers: advantages of macromolecular therapeutics in vivo. Bioconjug. Chem. 3 (5), 351-362.

Martin, C.R., Kohli, P., 2003. The emerging field of nanotube biotechnology. Nat. Rev. Drug Discov. 2 (1), 29-37. 
Merkel, J.S., Michaud, G.A., Salcius, M., Schweitzer, B., Predki, P.F., 2005. Functional proteins microarrays: just how functional are they? Curr. Opin. Biotechnol. 16, 447-452.

Moosavi-Nejad, S.Z., Rezaei-Tavirani, M., Padiglia, A., Floris, G., Moosavi-Movahedi, A., 2001. Amine oxidase from lentil seedlings: energetic domains and effect of temperature on activity. J. Prot. Chem. 20 (5), 405-411.

Nahalka, J., Liu, Z., Chen, X., Wang, P.G., 2003. Superbeads: immobilization in "sweet" chemistry. Chemistry 9 (2), 372377.

Ogino, H., Ishikawa, H., 2001. Enzymes which are stable in presence of organic solvents. J. Biosci. Bioeng. 91 (2), 109-116.

Podgornik, A., Tennikova, T.B., 2002. Chromatographic reactors based on biological activity. Adv. Biochem. Eng. Biotechnol. 76, 165-210.

Rauf, S., Ihsan, A., Akhtar, K., Ghauri, M.A., Rahman, M., Anwar, M.A., Khalid, A.M., 2006. Glucose oxidase immobilization on a novel cellulose acetate-polymethylmethacrylate membrane. J. Biotechnol. 121, 351-360.

Roe, H.R., Mitchell, J.J., 1951. Determination of small concentrations of carbonyl compounds by differential $\mathrm{pH}$ method. Anal. Chem. 23, 1758-1760.
Sommazzi, A., Garbassi, F., 1997. Olefin-carbon monoxide copolymers. Prog. Polym. Sci. 22, 1547-1605.

Stevanato, R., Mondovi', B., Sabatini, S., Rigo, A., 1990. Spectrophotometric assay for total polyamines by immobilized amine oxidases. Anal. Chim. Acta 237, 391-397.

Turini, P., Sabatini, S., Befani, O., Chimenti, F., Casanova, C., Riccio, P., Mondovì, B., 1982. Purification of bovine plasma amine oxidase. Anal. Biochem. 125, 294-298.

Vavasori, A., Toniolo, L., Cavinato, G., 2004. Carbon monoxide-ethylene copolymerisation catalysed by $\left[\mathrm{PdCl}_{2}(\mathrm{dppp})\right]$ in methanol-water or in acetic acid-water as solvents (dppp $=1,3$-bis(diphenylphosphine)propane). J. Mol. Catal. A 215, 63-72.

Veronese, F.M., Morpurgo, M., 1999. Bioconjugation in pharmaceutical chemistry. II. Farmaco 54 (8), 497-516.

Vila, M.M., Tubino, M., De Oliveira Neto, G, 2001. Determination of salicylate in blood serum by flow injection with immobilized salicylate hydroxylase. J. AOAC Int. 84 (5), 1363-1369.

Wilmot, C.M., 2003. Oxygen activation in a copper-containing amine oxidase. Biochem. Soc. Trans. 31, 493-496.

Wu, L.C., Cheng, C.M., 2005. Flow-injection enzymatic analysis for glycerol and triacylglycerol. Anal. Biochem. 346 (2), 234-240. 